\title{
PREVALENCE AND PATTERN OF DYSLIPIDEMIA IN ACUTE CORONARY SYNDROME PATIENTS ADMITTED TO MEDICAL INTENSIVE CARE UNIT IN ZAGAZIG UNIVERSITY HOSPITAL, EGYPT
}

\author{
Addulla Abdelaziz and Mohamed S. Fawzy \\ Internal Medicine and Biochemistry Departments, Faculty of Medicine, Zagazig University
}

\begin{abstract}
Background and aim of the work : Coronary artery disease (CAD) is the leading cause of mortality in men and women. Acute coronary syndrome (ACS), is a major reason for hospitalization in our country. The great majority of ACS patients have at least one major risk factor. Dyslipidemia has been identified as one of the most important modifiable risk factors for CAD. The aim of the study was to determine the prevalence and pattern of dyslipidemia, its relation to other modifiable risk factors in patients admitted with ACS to Medical ICU in Zagazig University Hospital, Egypt within a period of 11 months.

Subjects and methods : The study included two groups; group one included 150 patients with ACS classified according to clinical presentation, the findings on the admission electrocardiogram (ECG) and the results of serial cardiac troponin levels, into myocardial infarction(MI), either ST-elevation or non ST- elevation MI, and unstable angina(UA) subgroups. The other group included 20 healthy subjects as controls. All subjects participated in this study were subjected to history, clinical examination routine investigations, lipid profile including total cholesterol (TC), high density lipoprotein (HDL), low desity lipoprotein (LDL) and triglycerides (TG) and lipoprotein (a) [Lp(a)] . Cardiac troponin and 12 leads ECGs were performed for diagnosis and follow up of the patients.

Results: In patients with ACS, high levels of TC (> $200 \mathrm{mg} / \mathrm{dl}$ ) were found in $60.67 \%$, high levels of LDL (>130 mg/dl) were found in $58 \%$, high levels of $\mathrm{TG}(>150 \mathrm{mg} / \mathrm{dl}$ ) were found in $63.33 \%$ and high levels of $\mathrm{Lp}(\mathrm{a})(>30 \mathrm{mg} / \mathrm{dl})$ were found in $62 \%$, however, low levels of $\operatorname{HDL}(<40 \mathrm{mg} / \mathrm{dl})$ were found in $66 \%$. There was a statistically significant elevation in TC, LDL, TG and Lp(a) serum levels in patients with ACS compared to control subjects $(\mathrm{p}<0.05)$ while the HDL was significantly low in ACS patient compared to control subjects ( $\mathrm{p}<0.05)$. TC/HDL $>5$ and TG/HDL $>4$ were significantly higher in patients with ACS than controls. There was no significant difference between MI and UA patients regarding all lipid profile parameters. TC, LDL, TG and [Lp(a)] were significantly higher in males than in females while HDL was significantly higher in females compared to males. Also TC/HDL and TG/HDL ratios were sigificanly higher in males compared to females. All lipid components were significantly more prevalent in males than in females except TG where there was no significant difference between males and females

The $L p(a)$ values were significantly elevated in diabetic and in smoker patients with ACS $(p<0.05)$ while the high values in hypertensive patients were insignificant $(\mathrm{p}=0.167)$. Stepwise regression analysis of lipid parameters revealed that TC/HDL and TG/HDL ratios were independant risk factors for ACS.

Conclution: Dyslipidemia is one the major risk factors which is widely prevalent in patients with ACS and is more prevalent in males than in females. High Lp (a) is widely prevalent amoung patients with ACS. specially those with diabetes mellitus and smokers. We recommend to pay more attention to serum lipids and other modifiable risk factors for prevention of ACS and more studies about Lp (a) as a risk factor of atherosclerosis and its impact on other systems is adviced.
\end{abstract}

\section{INTRODUCTION}

$\mathrm{C}$ oronary artery disease (CAD) is the leading cause of death in men and women [1]. Regardless of declines in developed countries, both CAD mortality and the prevalence of CAD risk factors continue to rise rapidly in developing countries [2].

The risk factors of CAD used for the categorization and setting of management targets have been established on the basis of evidence accumulated over a long time [3].

Hypertension, diabetes mellitus and Cigarette smoking have been reported to be risk factors of $\mathrm{CAD}$ and stroke through many studies $[4,5,6]$, respectively. The risk of CAD was about 4 and 3 times higher in male and female smokers than nonsmokers respectively [6].

Elevated levels of total- and low density lipoprotein cholesterol (TC and LDL-C),elevated levels of triglyceriges (TG) and low levels of high density lipoprotein cholesterol (HDL-C) are important risk factors for CAD [7]. LDL-C is considered as bad cholesterol' since too high level of this cholesterol is associated with an increased risk of coronary artery disease and stroke. Lp(a) is a LDL particle with apolipoprotein(a) [apo(a)] protein attached loosely to the surface by a disulfide bond linked to the only protein on LDL particle, namely apolipoprotein B (apoB). The same hazard is associated with elevated blood Lp(a) levels [8]. Epidemiologic and prospective studies have 
revealed elevated levels of $L p$ (a) in persons with CAD (Mark et al., 2003)[9].

Previous findings suggested that the content of oxidized phospholipids in $\mathrm{Lp}(\mathrm{a})$, constitutes an independent predictive marker for cardiovascular (CV) morbidity and mortality [10]

Apo (a) is a distinctive glycoprotein of $L p(a)$ and is structurally homologous to plasminogen' a key protein of the fibrinolytic system. Lp (a) does not have fibrinolytic activity and it competes with plasminogen for the binding site on surface of the endothelial cells. Thus it prevents the activation of plasminogen by the tissue plasminogen activator and may, therefore, promote a procoagulant state. Treating dyslipidemia has clear benefits in the primary and secondary prevention of coronary heart disease (CHD) in both sexes [11]. This study focused on dyslipidemia as a risk factor of acute coronary syndrome (ACS). The aim of the study was to determine the prevalence and pattern of dyslipidemia in subjects with acute coronary syndrome, its relation to age, gender and other modifiable risk factors .

\section{SUBJECTS AND METHODS}

This prospective, descriptive and observational study was carried out in the Medical Intensive Care Unit (ICU) of the Internal Medicine and Biochemistry Departments, Zagazig University Hospital, during the period from September 2012 to August 2013.

. The study included two groups:

Group I; included 150 patients with ACS with the age ranged from 42 to 81 years with a mean age \pm SD of $61.50 \mathrm{ys} \pm 8.24$. Male patients in the study were 91 (60.67\% of patients) [ mean age \pm SD (61.35 ys \pm 7.70$)]$ while female patients were 59 (39.33\% of patients) [mean age \pm SD (61.39 ys \pm 9.37$)]$. Regarding risk factors, we found that 94 patients $(62.67 \%$ of patients) were hypertensive, 79 patients (52.67\% of patients) were diabetic and 71 patients $(47.33 \%$ of patients) were smokers. All smokers were males.

ACS were classified according to clinical presentation, the findings on the admission electrocardiogram(ECG) and the results of serial cardiac troponin levels into;

-ST-elevation ACS (STE-ACS): patients presented with acute chest pain, persistent $(>20$ minutes) ST-segment elevation and a rise in troponin levels [ ST-elevation MI (STEMI)]. -Non-ST-elevation ACS (NSTE-ACS): patients presented with acute chest pain but without persistent ST-segment elevation. The ECG shows persistent or transient ST-segment depression or Twave inversion, flat $\mathrm{T}$ waves, pseudo-normalisation of $\mathrm{T}$ waves, or no ECG changes at presentation. NSTE-ACS is further divided into:

○ Unstable angina: normal troponin levels.

- Non-ST-elevation MI (NSTEMI): with a rise in troponin levels.

Group II; included 20 healthy subjects not diabetic, not hypertensive and nonsmokers. Their ages ranged from 49 to 62 years with a mean age of $57 \mathrm{ys} \pm 3.53$ years. They were 11 males and 9 females.

Exclusion Criteria: Patients with stable angina and those receiving hypolipidemic drugs were excluded from the study.

Methods: A written concent to participate in the study was taken from each subject.

All subjects participated in this study were subjected to the following:

1 -Thorough history of present illness and history of any other diseases including diabetes mellitus and hypertension. History of previous attacks of acute coronary syndrome and family history of ischemic heart disease were recorded, history of smoking and previous hospital admission were taken in consideration.

II Clinical examination with attention to:

a -Blood pressure, measured by a mercury sphygmomanometer with the subject recumbent in bed, with the arm supported and positioned at the level of the heart.

b-Pulse:

c-Cardiac examination:

III- Routine investigations :

- Complete blood count (CBC), lipid profile [total cholesterol (TC), high density lipoprotein (HDL), low desity lipoprotein (LDL) and triglycerides (TG), liver function tests, kidney function tests and fasting blood glucose level .

- ECG: 12 leads ECGs were performed for diagnosis and follow up of the case. 
Table (1): Normal and abnormal levels of lipid profile. [12].

\begin{tabular}{llll}
\hline & Recommended & Borderline & High risk \\
\hline TC & $<200 \mathrm{mg} / \mathrm{dl}$ & $200-240 \mathrm{mg} / \mathrm{dl}$ & $>240 \mathrm{mg} / \mathrm{dl}$ \\
\hline HDL & $\geq 40 \mathrm{mg} / \mathrm{dl}$ & $<40 \mathrm{mg} / \mathrm{dl}$ & \\
\hline LDL & $<130 \mathrm{mg} / \mathrm{dl}$ & $130-160 \mathrm{mg} / \mathrm{dl}$ & $>160 \mathrm{mg} / \mathrm{dl}$ \\
\hline TG & $<150 \mathrm{mg} / \mathrm{dl}$ & $150-200 \mathrm{mg} / \mathrm{dl}$ & $>200 \mathrm{mg} / \mathrm{dl}$ \\
\hline
\end{tabular}

Specific investigations:

a- Troponin: Cardiac Troponin assay was done using a latex enhanced immunoturbidimetric method. [13].

b- Lipoprotein (a) :Lp(a) were measured by a quantitative turbidimetric test for the measurement of Lp (a) in human serum or plasma. According to the used kits, the normal and abnormal levels of $\mathrm{Lp}(\mathrm{a})$ were as the following; desirable values was $<14 \mathrm{mg} / \mathrm{dL}$, borderline risk values ranged from $14-30$ $\mathrm{mg} / \mathrm{dL}$ and high risk values ranged from $31-50$ $\mathrm{mg} / \mathrm{dL}$ [14].

Blood samples : First sample: $5 \mathrm{ml}$ blood were withdrawn from each case on admission, cenerfuged

\section{RESULTS}

Table (2): Disease distribution in the study.

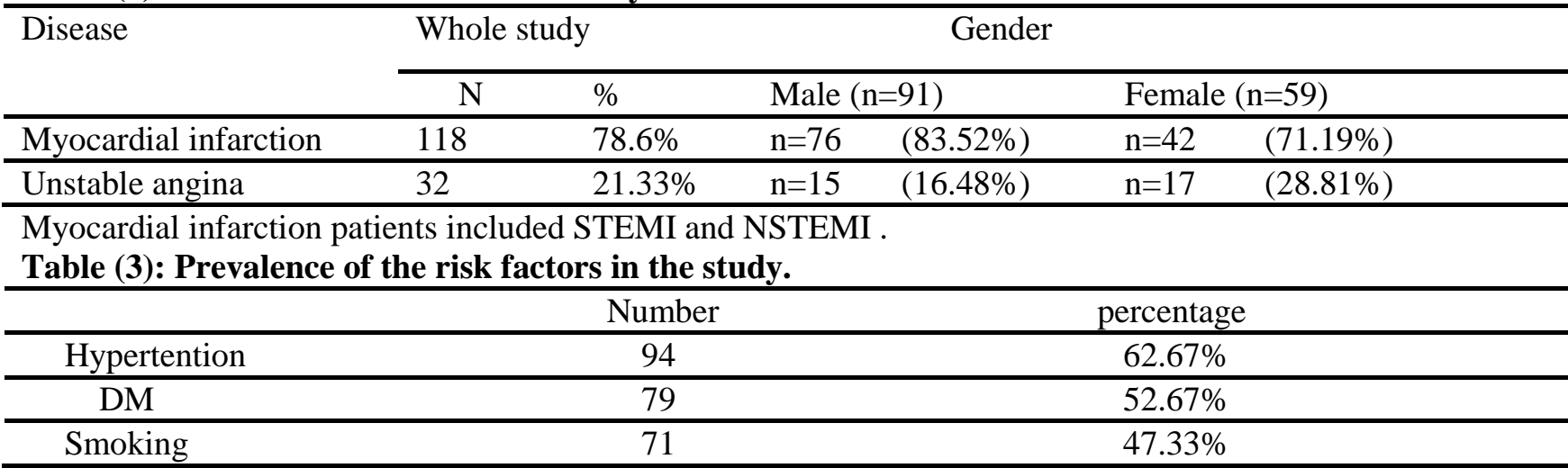

Hypertension was found in 94 patients (62.67\% of subjects). 79 patients were diabetics (52.67\% of patients). Finaly, smoking was a habit in 71 patients $(47.33 \%$ of patients).

Table (4): Prevalence of the risk factors in relation to gender and ACS.

\begin{tabular}{lllllll}
\hline & Hypertention & & DM & \multicolumn{3}{l}{ Smoking } \\
\hline & Number & $\%$ & Number & $\%$ & Number & $\%$ \\
\hline Males & 65 & $71.43 \%$ & 45 & $49.45 \%$ & 71 & $78.02 \%$ \\
\hline Females & 39 & $66.10 \%$ & 34 & $57.63 \%$ & 0 & $0 \%$ \\
\hline MI & 79 & $66.95 \%$ & 63 & $53.39 \%$ & 59 & $50 \%$ \\
\hline UA & 15 & $46.88 \%$ & 16 & $50 \%$ & 12 & $37.50 \%$ \\
\hline P & 0.023 & & 0.231 & & 0.037 & \\
\hline
\end{tabular}

$\mathrm{P}<0.05$ means a significant difference between MI and UA regarding the modifiable risk factors.

This table showed that hypertention was more prevalent in males than females, DM was more prevalent in females than in males while all smokers were males. Also it showed that hypertention and at $3000 \mathrm{rpm}$ for 10 minutes, serum was used for routine investigation and for troponin . second sample ; from each case and from the controls,and after overnight fasting of 12 hours, $5 \mathrm{ml}$ blood were withdrawn centerfuged at $3000 \mathrm{rpm}$ for 10 minutes10 minutes Serum was used for lipid profile and. $1 \mathrm{ml}$ of serum was kept at $-20^{\circ} \mathrm{C}$ for measurement of lipoprotein (a).

Statistical Analysis : Statistical presentation and analysis of the collected data were conducted, using the mean, standard deviation, analysis of variance [ANOVA] test and chi-square test by the SPSS statistical software version 18 for windows [15]. 
Table (5): Prevalence and pattern of dyslipidemia in patients with ACS.

\begin{tabular}{|c|c|c|c|}
\hline Type of lipid & & Number & Percentage \\
\hline Total cholesterol & $(>200 \mathrm{mg} / \mathrm{dl})$ & 91 & $60.67 \%$ \\
\hline Low density lipoprotein [ LDL] & $(>130 \mathrm{mg} / \mathrm{dl})$ & 87 & $58 \%$ \\
\hline High density lipoprotein [HDL] & $(<40 \mathrm{mg} / \mathrm{dl})$ & 99 & $66 \%$ \\
\hline Triglycerides & $(>150 \mathrm{mg} / \mathrm{dl})$ & 95 & $63.33 \%$ \\
\hline Lipoprotein (a) & $(>30 \mathrm{mg} / \mathrm{dl})$ & 93 & $62 \%$ \\
\hline
\end{tabular}

This table showed high levels of TC (more than $200 \mathrm{mg} / \mathrm{dl})$ were found in 91 patients $(60.67 \%$ of patients), high levels of LDL (more than 130 $\mathrm{mg} / \mathrm{dl}$ ) were found in 87 patientts (58\% of patients), high levels of TG (more than $150 \mathrm{mg} / \mathrm{dl}$ ) were found in 95 subjects $(63.33 \%$ of patients) and high levels of $\mathrm{Lp}(\mathrm{a})($ more than $30 \mathrm{mg} / \mathrm{dl})$ were found in 93 patients $(62 \%)$. However, low levels of HDL (less than $40 \mathrm{mg} / \mathrm{dl}$ ) were found in 99 patients $(66 \%$ of patients).

Table (6): Comparison between lipid profile parameters in patients with ACS and control subjects.

\begin{tabular}{llll}
\hline & Control group $($ Mean \pm SD) & ACS group $($ Mean \pm SD) & p-value \\
\hline TC $(\mathrm{mg} / \mathrm{dl})$ & $167.45 \pm 3.23$ & $217.87 \pm 43.61$ & 0.023 \\
\hline $\mathrm{LDL}(\mathrm{mg} / \mathrm{dl})$ & $97.67 \pm 6.42$ & $139.25 \pm 38.43$ & 0.02 \\
\hline $\mathrm{HDL}(\mathrm{mg} / \mathrm{dl})$ & $49.65 \pm 2.32$ & $37.88 \pm 4.79$ & 0.034 \\
\hline $\mathrm{TG}(\mathrm{mg} / \mathrm{dl})$ & $137.41 \pm 5.78$ & $174.41 \pm 61.42$ & 0.043 \\
\hline $\mathrm{Lp}(\mathrm{a})(\mathrm{mg} / \mathrm{dl})$ & $22.65 \pm 4.87$ & $53.26 \pm 41.59$ & 0.008 \\
\hline TC/HDL & 3.37 & 5.75 & 0.015 \\
\hline TG/HDL & 2.77 & 4.604 & 0.032 \\
\hline
\end{tabular}

$* \mathrm{p}<0.05=$ significant

This table showed that there was a statistically significant elevation in TC (total cholesterol), LDL (low density lipoprotein), TG (triglyceride) and Lp(a) [lipoprotein(a)] serum levels in patients with ACS compared to control subjects while the HDL

(high density lipoprotein) was significantly low in ACS patients compared to control subjects. $\mathrm{TC} / \mathrm{HDL}>5$ and $\mathrm{TG} / \mathrm{HDL}>4$ were significantly higher in patients with ACS than controls.

Table (7): Comparison between lipid profile parameters in MI and UA patients.

\begin{tabular}{llll}
\hline & Myocardial Infarction (Mean \pm SD) & Unstable Angina (Mean \pm SD) & P \\
\hline TC $(\mathrm{mg} / \mathrm{dl})$ & $217.84 \pm 44.99$ & $217.97 \pm 38.75$ & $\mathbf{N S}$ \\
\hline LDL $(\mathrm{mg} / \mathrm{dl})$ & $139.34 \pm 39.94$ & $138.91 \pm 32.82$ & $\mathbf{N S}$ \\
\hline HDL $(\mathrm{mg} / \mathrm{dl})$ & $37.80 \pm 4.77$ & $38.15 \pm 4.91$ & $\mathbf{N S}$ \\
\hline TG $(\mathrm{mg} / \mathrm{dl})$ & $176.45 \pm 66.04$ & $175.75 \pm 52.95$ & $\mathbf{N S}$ \\
\hline Lp $(\mathrm{a})(\mathrm{mg} / \mathrm{dl})$ & $56.19 \pm 43.29$ & $42.44 \pm 32.96$ & $\mathbf{N S}$ \\
\hline TC/HDL & 5.74 & 5.71 & $\mathbf{N S}$ \\
\hline TG/HDL & 4.72 & 4.60 & $\mathbf{N S}$ \\
\hline
\end{tabular}

$* \mathrm{p}<0.05$ means significant.

There was no significant difference between myocardial infarction and unstable angina regarding all parameters. 
Table (8): Pattern of dyslipidemia in ACS patients in relation to gender.

\begin{tabular}{llll}
\hline & Male $($ Mean \pm SD) & Female $($ Mean \pm SD) & P \\
\hline TC $(\mathrm{mg} / \mathrm{dl})$ & $225.17 \pm 43.90$ & $206.61 \pm 41.02$ & 0.01 \\
\hline LDL $(\mathrm{mg} / \mathrm{dl})$ & $146.18 \pm 40.14$ & $128.56 \pm 33.19$ & 0.006 \\
\hline HDL $(\mathrm{mg} / \mathrm{dl})$ & $3\urcorner \pm 4.64$ & $\varepsilon r .91 \pm 4.86$ & 0.034 \\
\hline TG $(\mathrm{mg} / \mathrm{dl})$ & $183.54 \pm 66.18$ & $163.64 \pm 57.37$ & 0.012 \\
\hline Lp(a) $(\mathrm{mg} / \mathrm{dl})$ & $60.26 \pm 44.53$ & $42.46 \pm 34.23$ & 0.007 \\
\hline TC/HDL & 6.19 & 4.81 & 0.037 \\
\hline TG/HDL & 5.04 & 3.85 & 0.029 \\
\hline
\end{tabular}

$* \mathrm{p}<0.05$ means significant.

TC, LDL, TG and Lp(a) were significantly higher in males than in females while HDL was significantly higher in females compared to males. Also TC/HDL and TG/HDL ratios were significanly higher in males compared to females.

Table (9): Prevalence of dyslipidemia in ACS patients in relation to gender.

\begin{tabular}{lllllll}
\hline & & Male $(\mathrm{n}=91)$ & \multicolumn{3}{c}{ Female(n=59) } & p-value \\
\hline TC & $(>200 \mathrm{mg} / \mathrm{dl})$ & 60 & $65.93 \%$ & 31 & $52.54 \%$ & 0.023 \\
\hline LDL & $(>130 \mathrm{mg} / \mathrm{dl})$ & 60 & $65.93 \%$ & 27 & $45.76 \%$ & 0.042 \\
\hline HDL & $(<40 \mathrm{mg} / \mathrm{dl})$ & 65 & $71.43 \%$ & 34 & $57.63 \%$ & 0.011 \\
\hline TG & $(>150 \mathrm{mg} / \mathrm{dl}$ & 59 & $64.84 \%$ & 36 & $61.01 \%$ & 0.053 \\
\hline Lp(a) & $(>30 \mathrm{mg} / \mathrm{dl})$ & 62 & $68.13 \%$ & 31 & $52.54 \%$ & 0.008 \\
\hline
\end{tabular}

$* p<0.05$ means significant.

All components were significantly more prevalent in males than in females except TG where there was no significant difference between males and females

Table (10): Prevalence of lipoprotein (a) in relation to risk factors.

\begin{tabular}{llll}
\hline & Lp(a) $>\mathbf{3 0} \mathbf{~ m g} / \mathbf{d l}$ & & $\mathrm{P}<0.05=$ significant \\
\hline Hypertension & 61 patients & $64.90 \%$ & 0.167 \\
\hline DM & 54 patients & $68.35 \%$ & 0.045 \\
\hline Smoking & 53 patients & $74.65 \%$ & 0.021 \\
\hline
\end{tabular}

The Lp(a) values were significantly elevated in diabetic and in smoker patients with ACS while the high values in hypertensive patients were insignificant.

Table (11): Stepwise regression analysis of dyslipidemia in relation to ACS.

\begin{tabular}{|c|c|c|c|c|c|c|}
\hline & \multirow[t]{2}{*}{ B } & \multirow{2}{*}{$\begin{array}{l}\text { Std. Error } \\
\text { for B }\end{array}$} & \multirow[t]{2}{*}{$\boldsymbol{\beta}$} & \multirow[t]{2}{*}{ Sig. } & \multicolumn{2}{|c|}{$\begin{array}{l}95 \% \text { Confidence } \\
\text { Interval for B } \\
\end{array}$} \\
\hline & & & & & Lower & Higher \\
\hline $\mathrm{TC}$ & .000 & .003 & -.034 & NS & -.007 & .006 \\
\hline LDL & .000 & .003 & .032 & NS & -.006 & -.006 \\
\hline HDL & .003 & .008 & .040 & NS & -.012 & .019 \\
\hline$\overline{\mathrm{TG}}$ & .000 & .001 & -.141 & NS & -.002 & .002 \\
\hline TC/HDL & 2.435 & 1.231 & 0.031 & Sig. & 1.549 & 78.86 \\
\hline TG/HDL & 2201 & 0.768 & 0.41 & Sig. & 1.386 & 56.12 \\
\hline $\mathrm{Lp}(\mathrm{a})$ & -.001 & .001 & -.141 & NS & -.003 & .000 \\
\hline (Constant) & 1.133 & .364 & --- & 0.002 & --- & --- \\
\hline
\end{tabular}




\section{DISCUSSION}

CAD is a complex and multifactorial process that manifestes as stable angina, unstable angina or myocardial infarction. The atherosclerotic process underlies each of these pathologies. Indeed, clinical symptomatology in CAD is frequently triggered by a thrombus formation on an eroded or ruptured atherosclerotic, lipid-rich plaque characterized by a thin fibrous cap [16].

CAD is the leading cause of death in men and women [1]. Dyslipidemia preponderated among the nine major risk factors (smoking, diabetes, hypertension, visceral obesity, psychosocial stress, sedentary life, low fruit and vegetable consumption and alcohol consumption), and alone accounted for more than $50 \%$ of population attributable risk [17]. Regardless of declines in developed countries, both CAD mortality and the prevalence of CAD risk factors continue to rise rapidly in developing countries [2]. Hypertension is a clear risk factor of atherosclerotic CAD [18]. The risk of CAD has been reported to be 2-6 times higher in diabetics than in non-diabetics [4]. Cigarette smoking has been reported to be a risk factor of CAD and stroke through many studies [5]. The risk of CAD was about 4 and 3 times higher in male and female smokers than nonsmokers respectively [6].

Dydlipidemia, manifested by elevated levels of total- and low density lipoprotein cholesterol (TC, LDL-C), low levels of high density lipoprotein cholesterol (HDL-C) and high levels of triglycerides (TG), is an important risk factor for CAD [19] The relationship of $\mathrm{Lp}(\mathrm{a})$ to $\mathrm{CAD}$ is considered to be due to interference by $L p(a)$ with the physiologic roles of plasminogen in the fibrinolytic system. Moreover, $\mathrm{Lp}(\mathrm{a})$ is speculated to promote arteriosclerosis by inducing cholesterol deposition in the vascular wall, proliferation of vascular wall cells, and binding of cholesterol to oxidized phospholipids [20]

Our study revealed that hypertension is the most common risk factor of ACS (62.67\%) followed by diabetes mellitus (52.67\%). Cigarette smoking came at the last $(47.33 \%)$. Our results agreed with Sandhu et al., Lahoz et al., and Cooke et al., (2006).[21, 22, 23].

Saito et al., [24] found that the prevalence of hypertension was $45.8 \%$, diabetes mellitus was $15.8 \%$ while cigarette smoking was $16.7 \%$ which differs regarding the prevalence from our study. According to Saito et al., [24], hypertension was the commonest risk factor of acute coronary syndrome followed by cigarette smoking, diabetes mellitus came at the last. In our study smoking, as a risk factor for ACS, came after hypertention and diabetes mellitus, probably, because all our female patients (39.33\% of our subjects) were nonsmoker. Our study revealed that myocardial infarction (MI) was found in 118 patients (78.67\% of patients) while unstable angina (UA) was found in 32 patients $(21.33 \%$ of patients). In MI, 79 patients $(66.95 \%)$ were hypertensive, 63 patients $(53.39 \%)$ were diabetic and 59 patients $(50 \%)$ were smokers. On the other hand, in UA, 15 patients $(46.88 \%)$ were hypertensive, 16 patients $(50 \%)$ were diabetic and 12 patients $(37.50 \%)$ were smokers. The increased prevalence of hypertention and smoking were significant in patients with MI $(p<0.05)$ compared to those with UA while it was insignificant regarding diabetes, [table, 5]. Esteghamati et al.,[25], in agreement with our results, found that the prevalence of hypertension and smoking were significantly higher in patients with MI compared to those with UA ( $96 \%$ vs $89.2 \%$ for hypertention and $52.8 \%$ vs $38.6 \%$ for smoking) while diabetes mellitus was significantly higher in patients with MI compared to patients with UA which was different from our results (44.6\% vs $25.2 \%$ ). Also our results revealed that there was no significant difference between patients with MI and UA regarding all lipid profile parameters(Table,7) which did not agree with that of Guler et al., [26], and Esteghamati et al., [25] who reported that Low levels of HDL were significantly low in subjects with MI compared to those with UA.

Regarding prevalence and pattern of dyslipidemia in our study, [table, 6], we found that high levels of TC (more than $200 \mathrm{mg} / \mathrm{dl}$ ) were found in 91 patients $(60.67 \%$ of patients) [mean \pm SD (217.87 $\mathrm{mg} / \mathrm{dl} \pm 43.61$ )]. High levels of LDL (more than 130 $\mathrm{mg} / \mathrm{dl}$ ) were found in 87 patients (58\% of patients) [mean \pm SD $(139.25 \mathrm{mg} / \mathrm{dl} \pm 38.43)]$. Low levels of HDL (less than $40 \mathrm{mg} / \mathrm{dl}$ ) were found in 99 patients ( $66 \%$ of patients) [mean \pm SD $(37.88 \mathrm{mg} / \mathrm{dl} \pm 4.79)]$. High levels of TG (more than $150 \mathrm{mg} / \mathrm{dl}$ ) were found in 95 patients $(63.33 \%$ of patients) [mean \pm SD $(174.41 \mathrm{mg} / \mathrm{dl} \pm 61.42)]$.Also, our results revealed that the TC/HDL ratio was more than five (TC/HDL >5) and TG/HDL ratio was more than four (TG/HDL $>4)$. . According to the American Heart Association, the goal is to keep TC/HDL ratio $<5$ and $\mathrm{TG} / \mathrm{HDL}<4$. A higher ratios indicates a higher 
risk of heart disease; a lower ratio indicates a lower risk.

Finaly, high levels Lp(a) (more than $30 \mathrm{mg} / \mathrm{dl}$ ) were found in 93 patients (62\% of patients).

Assessment of lipid profile parameters revealed that there was a statistically significant elevation in serum levels of TC, LDL, TG, TC/HDL, TG/HDL and $\mathrm{Lp}(\mathrm{a})$ in ACS patients compared with the control subjects while regarding HDL it was significantly low in ACS patients compared to the control subjects $(\mathrm{p}<0.05)$ [Table, 8]. Our results were in agreement with that of Kamariya et al., [27] and Yadav and Bhagwat [19] who reported increased TC, TG, LDL, Lp(a) and decreased HDL levels in patients with ACS than controls .

The prevalence of MI was higher in male gender than females $(83.52 \%$ vs $71.19 \%$ respectively )[table,2]. This can be explained by our finding that hypertension and smoking were more prevalent in males than in females. Smokers were only males. Regarding the prevalence of diabetes, there were 45 diabetic males (49.45\%) vs 34 diabetic females $(57.63 \%)$ which was statisticaly insignificant [table,4]. Another factor which can explain occurrence of MI in males than females was the more prevalent dyslipidemia in male than female patients [Table, 7]. Our results agreed with that of Leebmann et al.,[28], El-Menyal et al,[29], Youssef et al., [30] and Noureddine et al., [31] who reported that MI was more prevalent in males than females.

The prevalence of dyslipidemia and its pattern in patients with ACS were more significant in males than females $(\mathrm{p}<0.01)$ [tables 8 \& 10].

The same findings were present for $\mathrm{Lp}$ (a) which were significantly more prevalent in male patients compared to females $(p<0.05)$ while Low levels of HDL $(<40 \mathrm{mg} / \mathrm{dl})$ were significant in male patients patients compared to female patients $(\mathrm{p}=0.034)$, ( $71.43 \%$ of male patients with mean \pm SD of HDL of $37 \mathrm{mg} / \mathrm{d} 12.1 \pm 4.64)$ vs $(65.63 \%$ of female patients with the mean \pm SD of HDL of $\leqslant r .91 \mathrm{mg} / \mathrm{dl} \pm 4.86$ )

A higher levels of TG [mean \pm SD $(174.41 \mathrm{mg} / \mathrm{dl} \pm 61.42)]$ were found in males compared to that in females [ mean \pm SD $(173.41 \mathrm{mg} / \mathrm{dl} \pm 5,78)]$, which was insignificant $(\mathrm{p}=\mathrm{o.172})$. These results were the same results of Jacob et al., [32] who reported that men had higher TG and TC levels and lower HDL-levels compared to women $(\mathrm{P}<0.001)$. On the other hand, Esteghamati et al., [25] found that mean levels of
TG were lower in male patients [170.6 $\pm 97.3 \mathrm{mg} / \mathrm{dl}]$ than in female patients $[188.4 \pm 88.3 \mathrm{mg} / \mathrm{dl}]$. That would be due to differences in genetics, body fat distribution, life styles and dietary habits between different countries where studies were carried out.

Our results revealed that high $\mathrm{Lp}(\mathrm{a})$ values were more prevalent in males than females, $(68.13 \%$ of male patients vs $5254 \%$ of female patients). Also $\mathrm{Lp}$ (a) values were significantly higher in male than female patients with a mean \pm SD of $60.26 \mathrm{mg} / \mathrm{dl}$ \pm 44.53 vs in males vs a mean \pm SD of $42.46 \mathrm{mg} / \mathrm{dl} \pm 34.23$ in females respectively ( $p<$ 0.007). Guler et al., [26] and Lima et al., [33] reported the same findings

In relation to risk factors, we found that $\mathrm{Lp}$ (a) was significantly higher in diabetics and smokers than nondiabetics and nonsmokers but there was no significant difference regarding hypertention in our patients. Jatav et al., [34] found that levels of lipoprotein (a) were significally higher in diabetic patients (87\%) than in non-diabetic ones $(61 \%)$ $(\mathrm{p}<0.05)$, which agreed with our results.

Although lipoprotein (a) was significantly prevalent in diabetics which is mildly more common in females, smoking increases levels of lipoprotein (a) which might be the cause that levels of lipoprotein (a) were significantly higher in males than in females, as smoking was prevalent in our males patients only [35]. Using stepwise regression of lipid profile parameters we found that TC/HDL and TG/HDL ratios were independant risk factors for ACS.

In conclution this study revealed that hypertension was the most common risk factor followed by diabetes mellitus. Smoking was the last risk factor. Hypertension and smoking were more prevalent in males than in females. Regarding dyslipidemia, we found that dyslipidemia was prevalent in ACS patients compared to control. Low level of HDL was the most common, followed by high TG, high Lp(a), high TC then high level of LDL, TC/HDL and TG/HDL ratios. Dyslipidemia was significantly related to gender. TC, LDL, TG and $\mathrm{lp}$ (a) were significantly higher in males than in females. There was no significant difference between patients with MI and those with UA regarding all lipid profile parameters. We also found that HDL was significantly lower in male than females. High levels of $\mathrm{Lp}$ (a) were prevalent in $62 \%$ of patients with ACS. It was significantly higher in males than in females. We also found that high level of $L p(a)$ was significantly higher in diabetics than non- 
diabetics. Generally, except HDL, levels of all types of dyslipidemia were higher in males than in females. Using backward stepwise logestic regression analysis of dyslipidemia, we found that TC/HDL and TG/HDL ratios were independant risk factors for ACS.

Based on these results, we can recommend to pay more attention to serum lipids for prevention of acute coronary syndrome, periodic check of fasting lipid profile and enriching the people culture about dyslipidemia, its hazards and how to avoid. Further studies about LP (a) as a risk factor of atherosclerosis and its impact on other systems.

\section{REFERENCES}

1-Thom T, Haase N, Rosamond W, et al. (2006): Heart Disease and Stroke. Statistics-2006 Update. AReport from the American Heart Association Statistics Committee and Stroke Statistics Subcommittee. Circulation. 113:e85.

2-Okrainec K, Banerjee DKand Eisenberg MJ.(2003): Coronary artery disease in the developing world. Am Heart J.;148:7-15.

3-Ueshima H, Choudhury SR, Okayama A, Hayakawa T, Kita Y, Kadowaki T, Okamura T, Minowa M, and Iimura O;NIPPON DATA80 Research Group(2004): Cigarette Smoking as a Risk Factor for Stroke Death in Japan: NIPPON DATA80. Stroke, 35:1836-1841.

4-Haffner SM, Lehto S, Rönemaa T, Pyörälä K, and Laakso M(1998): Mortality from coronary heart disease in subjects with type 2 diabetes and in nondiabetic subjects with and without prior myocardial infarction. N Engl J Med, 339:229-234

5-Wolf PA, D'Agostino RB, Kannel WB, Bonita R, and Belanger AJ(1988): Cigarette smoking as a risk factor for stroke: the Framingham Study. JAMA, 259:1025-1029.

6-Baba S, Iso H, Mannami T, Sasaki S, Okada K, and Konishi M; Shoichiro Tsugane; JPHC Study Group(2006): Cigarette smoking and risk of coronary heart disease incidence among middle-aged Japanese men and women; the JPHC Study Cohort . Eur J Cardiovasc Prev Rehabil, 13:207-213.

7-Yadav Arvind S and Bhagwat Vinod R (2012): Lipid Profile Pattern in Anginal Syndrome Patients From Marathwada Region of Maharashtra State Journal of Medical Education \& Research, Vol. 2, No.2, 12-15. July-Dec 2012

8-Emerging Risk Factors Collaboration, Erqou S, Kaptoge S, Perry PL, Di Angelantonio E, Thompson A, White IR, Marcovina SM, Collins R, Thompson SG, Danesh J. Lipoprotein(a) concentration and the risk of coronary heart disease, stroke, and nonvascular mortality.JAMA. $2009 \mathrm{Jul}$ 22;302(4):412-23.
9- Mark A. H., Santica M. Marcovina,et al,. (2003): Inhibition of Plasminogen Activation by Lipoprotein(a).Journal of Biological Chemistry. June $27, .23260-69$.

10-Kiechl S, Willeit J, Mayr M, et al. (2007): Oxidized phospholipids, lipoprotein(a), lipoprotein-associated phospholipase A2 activity, and 10-year cardiovascular outcomes: prospective results from the Bruneck study. ArteriosclerThromb Vasc Biol. 27(8):1788-1795.

11-Kakafika AI, Athyros VG, Tziomalos K, Karagiannis A, Mikhailidis DP.(2008): Primary and secondary coronary heart disease prevention using statins: is targeting Adam or Eve equally effective? Expert Opin Pharmacother 9:1437-40.

12-JAMA, (2001): Executive Summary of the Third Report of the National Cholesterol Education Program (NCEP), Adult Treatment Panel III (ATP III). JAMA; 285(19):2486-2497.

13-Thygesen K, Mair J, Katus H, Plebani M, Venge P, Collinson P, Lindahl B, Giannitsis E, Hasin Y, Galvani M, Tubaro M, Alpert JS, Biasucci LM, Koenig W, Mueller C, Huber K, Hamm C, Jaffe AS(2010): Study Group on Biomarkers in Cardiology of the ESC Working Group on Acute Cardiac Care. Recommendations for the use of cardiac troponin measurement in acute cardiac care. Eur Heart J31:2197 - 2204.

14-Ryan, George M and Julius Torelli, (2005): Beyond cholesterol: 7 life saving heart disease tests that your doctor may not give you. New York: St. Martin's Griffin. p. 91.

15-Yadolah (2003):The Oxford Dictionary of Statistical Terms. Oxford University Press. ISBN 0-19-9206139.

16-Libby, P. (2008): The molecular mechanisms of the thrombotic complications of atherosclerosis. J Intern Med 263, 517-527.

17-Yusuf, S., Hawken, S., Ounpuu, S., Dans, T., Avezum, A., Lanas, F., et al. (2004): Effect of potentially modifiable risk factors associated with myocardial infarction in 52 countries (the INTERHEART study): case-control study. Lancet 364, 937-952.

18-Kannel WB(2000): Fifty years of Framingham Study contributions to understanding hypertension. J Hum Hypertens, 14:83-90

19-Yadav Arvind S and Bhagwat Vinod R (2012): Lipid Profile Pattern in Anginal Syndrome Patients From Marathwada Region of Maharashtra State. Journal of Medical Education \& Research, Vol. 2, No.2, 12-15. July-Dec 2012

20- Tsimikas S, Brilakis ES, Miller ER, McConnell JP, Lennon RJ, Kornman S, Witztum JL, and Berger PB(2005): $\quad$ Oxidized phospholipids, Lp(a) lipoprotein, and coronary artery disease. $\mathrm{N}$ Engl J Med, 353:46-57. 
21-Sandhu K, Singh A, Nadar S(2012): Management of elderly patients with troponin positive chest pain in a District General Hospital. Cardiol J 19, 4: 395-401.

22-Lahoz C, Mostaza J, Tranche S Martin-Jadraque R21Tsimikas S, Brilakis ES, Miller ER, McConnell JP, Lennon RJ, Kornman, Mantilla M, Lopez-Rodriguez I, Monteiro B, Sanchez-Zamorano M, Taboada $M$ (2012): Atherogenic dyslipidemia in patients with established coronary artery disease. Nutrition, Metabolism \& Cardiovascular Diseases 22, 103e108

23-Cooke C, Hammerash W.(2006): Retrospective review of sex differences in the management of dyslipidemia in coronary heart disease: an analysis of patient data from a maryland-based health maintenance organization. Excerpra Medica, 28: 591-599.

24-Saito Y, Kita T, Mabuchi H, Matsuzaki M, Matsuzawa Y, Nakaya N, Oikawa S, Sasaki J, Shimamoto K, Itakura H(2010): Obesity as a risk factor for coronary events in japanese patients with hypercholesterolemia on low-dose simvastatin therapy. J Atheroscler Thromb, 17:270-277.

25-Esteghamati A, Abbasi M, Nakhjavani M, Yousefizadeh A, Basa A, Afshar H.(2006): Prevalence of diabetes and other cardiovascular risk factors in an Iranian population with acute coronary syndrome. Cardiovascular Diabetology 5:15 .

26-Guler E, Gecmen C, Guler G, Karacal O, Agus H, Gunes H, Batgerel U, Elveran A, Esen A(2013): Adding lipoprotein(a) levels to the GRACE score to predict prognosis in patients with non-ST elevation acute coronary syndrome. Kardiologia Polska 71, 7: 695-701;

27-Kamariya ,C P Jignesh H. Gorasia,Uday Vachhani, Mukesh Gohel.(2014); Evaluation of serum lipoprotein (a) in young patients with myocardial infarction. International Journal of Medicine and Public Health, Vol (4 ) Issue 1.107-109.

28-Leebmann J1, Roeseler E, Julius U, Heigl F, Spitthoever R, Heutling D, Breitenberger P, Maerz
W, Lehmacher W, Heibges A, Klingel R; (2013): Lipoprotein apheresis in patients with maximally tolerated lipid-lowering therapy, lipoprotein(a)hyperlipoproteinemia, and progressive cardiovascular disease: prospective observational multicenter study. Circulation. 17;128(24):2567-76.

29-El-Menyar A, Ahmed E, Albinali H, Al-Thani H, Gehani A, Singh R, Al Suwaidi J.(2013): Mortality trends in women and men presenting with acute coronary syndrome: insights from a 20-year registry.PLOS ONE 8(7): e70066.

30-Youssef A, Dimitry S, Saweris M.(2012): Clinical presentation of acute coronary syndrome in women and its difference from that in men.Heart Mirror $\mathbf{J}$ 6(2): 111-114

31-Noureddine S, Arevian M, Adra M, Puzantian H.(2008):Response to signs and symptoms of acute coronary syndrome: differences between Lebanese men and women. Am J Crit Care 17:26-35

32-Jacob C. Seidell, 1, Massimo Cigolini2, Jadviga Charzewska3,et al,.(1991): Fat distribution and gender differences in serum lipids in men and women from four European communities. Atherosclerosis 87:203-210.

33-. Lima L, Carvalho M, Loures-Vale A, Fernandes A, Mota A, Neto C, Garcia J, Saad J, Souza M(2005): Increased serum levels of lipoprotein(a) correlated with the severity of coronary artery disease in patients submitted to angiography. Arquivos Brasileiros de Cardiologia,

87. 34-Jatav O P, Agrawal N, Raghuvanshi A, Tiwari D.(2010): Serum lipoprotein(a) an independent risk factor of acute coronary syndrome. International Journal of Clinical Cases and Investigations. 1, 20-26

35-Swierszcz J, Dubiel JS, Milewicz T. et al (2009) : Smoking, increase in plasma lipoprotein (a) and triglycerides, as well as decrease in plasma HDLcholesterol concentrations seem to be linked with aortic valve stenosis and its progression. Przegl Lek.;66(4):159-65. Polish 
مدى شيوع ونمط اختلال دهون الدم فى مرضى قصور الثريان التاجى في وحدة العناية المركزة بقسم الباطنة العامة بمستثفيات جامعة الزقازيق

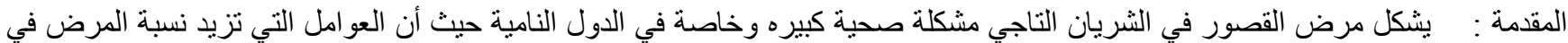

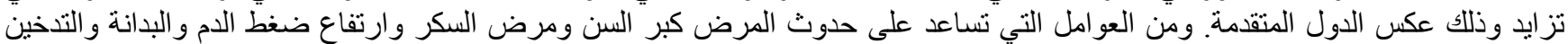

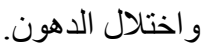

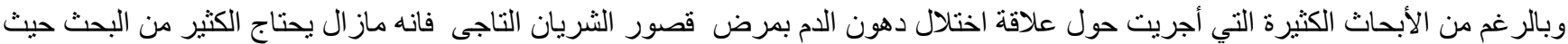

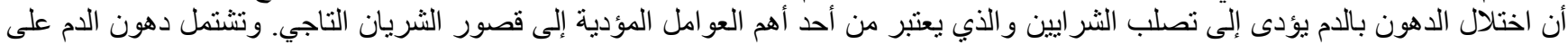

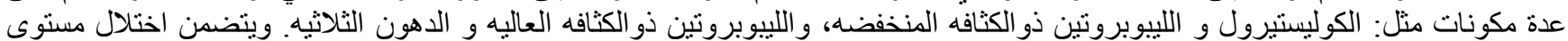

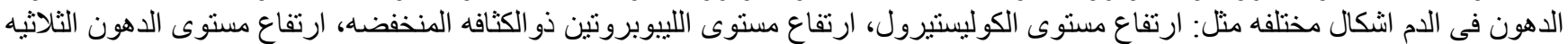

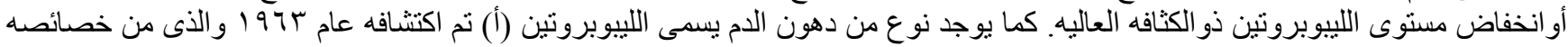

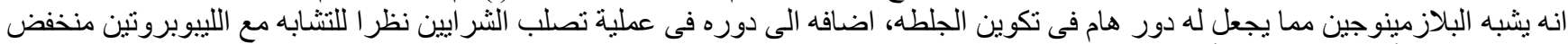

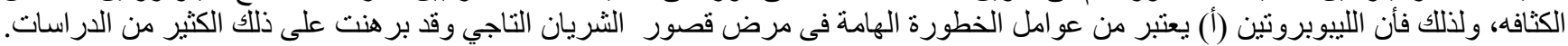

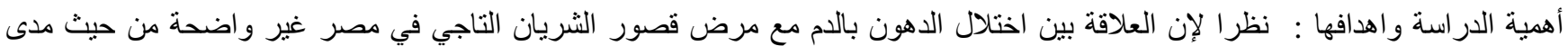

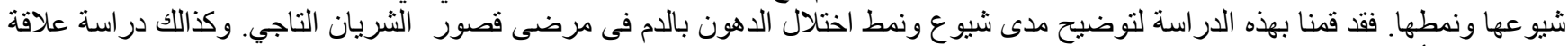

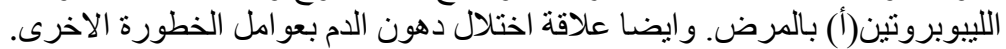

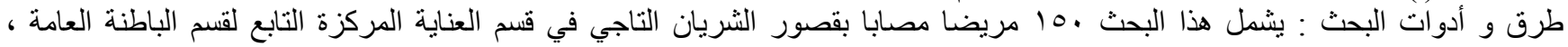

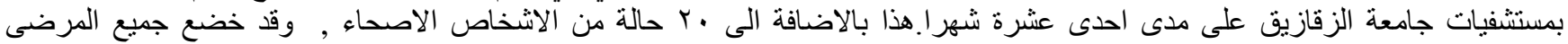

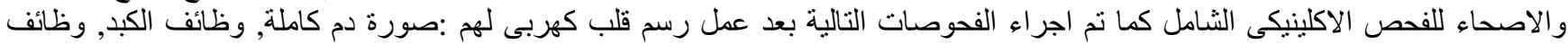

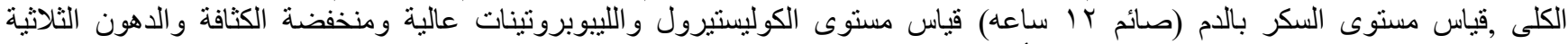

وتروبونين القلب وكذلك قياس نسبة الليبو بروتين(أ).

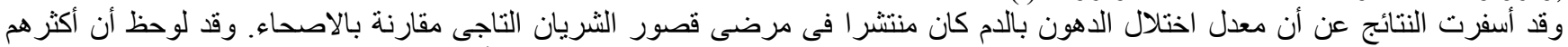

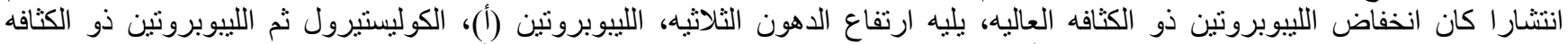

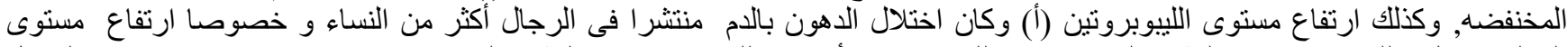

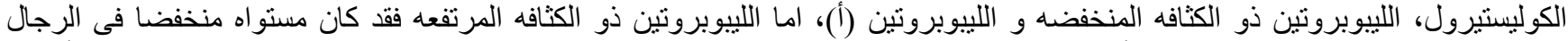

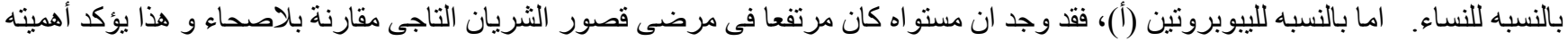

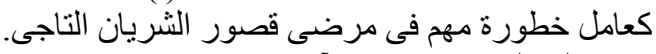
بناءا على النتائج نوصى بهى بالآتى:

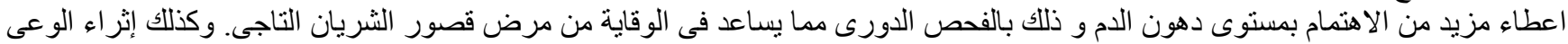

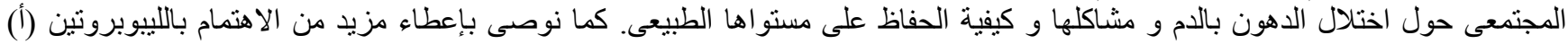

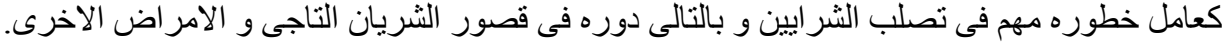

